\title{
Flood propagation simulation considering soil infiltration based on a fully hydrodynamic numerical model
}

\author{
Jingming Hou ${ }^{1}$, Zhaoan Zhang ${ }^{2}$, Dawei Zhang ${ }^{3}$, Hongli $\mathrm{Ma}^{4}$, Baoshan Shi $^{5}$, Guangzhao \\ Chen $^{5}$, and Hongbin Zhang ${ }^{3}$ \\ ${ }^{1}$ State Key Laboratory of Eco-hydraulics in Northwest Arid Region of China \\ ${ }^{2}$ State Key Laboratory of Eco-hydraulics in Northwest Arid Region of China \\ ${ }^{3}$ China Institute of Water Resources and Hydropower Research \\ ${ }^{4}$ Ordos Water Conservancy Survey and Design Institute \\ ${ }^{5}$ State Key Laboratory Eco-hydraulics Northwest Arid Region of China
}

June 25, 2020

\begin{abstract}
Traditional flood simulations fail to properly consider the impact of soil infiltration in floodplain areas with high soil infiltration rates. Notably, ignoring soil infiltration will lead to considerable uncertainty in flood simulations. In this paper, a fully hydrodynamic model coupled with the Green-Ampt infiltration model is used. Taking a natural reach in northern China (HTH in this paper) as a case study, observed flood discharge data are used to analyze the influence of soil infiltration on flood propagation based on the flood propagation simulation results for various inflow conditions. The results show that soil infiltration has little effect on the inundation area during the rising stage of a flood. In the late period a flood, the inundation area considering the effect of infiltration is smaller than that without infiltration, and the smaller the peak coefficient is, the longer the flood duration is, the larger the impact of infiltration on the inundation area. The research results provide a reference for flood management and post-disaster rescue efforts.
\end{abstract}

\section{Hosted file}

Manuscript.docx available at https://authorea.com/users/336856/articles/462528-floodpropagation-simulation-considering-soil-infiltration-based-on-a-fully-hydrodynamicnumerical-model

\section{Hosted file}

Figure.docx available at https://authorea.com/users/336856/articles/462528-flood-propagationsimulation-considering-soil-infiltration-based-on-a-fully-hydrodynamic-numerical-model

\section{Hosted file}

Table.docx available at https://authorea.com/users/336856/articles/462528-flood-propagationsimulation-considering-soil-infiltration-based-on-a-fully-hydrodynamic-numerical-model 